\title{
Outwitting repression of the media in PNG
}

'Papua New Guinea could possibly teach the rest of the world a thing or two about preserving press freedom. What has worked in the media's favour in PNG is the country's vibrant - you could say rampant - democracy.'

\section{By SEAN DORNEY}

PLEASE FORGIVE me for starting with a disclaimer. Although it is true that I was deported from Papua New Guinea in 1984 and that two years ago there was an attempt by the then Government to have me hauled before the PNG Parliament to be censured, no Papua New Guinea administration since independence in 1975 could really qualify for the description "repressive regime" when it comes to suppressing media freedom. I am not saying this simply to safeguard my residency status in Port Moresby - in fact, come the end of this year the $\mathrm{ABC}$ is pulling me out of Papua New Guinea. I am saying it because freedom of the press is something that the PNG media had fought to preserve. And it has succeeded in doing it.

No journalist in Papua New Guinea, for instance, has had to flee the country or been incarcerated in a freight container at military headquarters as I have learnt - from the booklet on Press Freedom in the Commonwealth the CPU has included in our conference kits - happened not so long ago to the president of the Sierra Leone Association of Journalists, Frank Kopsowa.

I am not saying that there has not been quite vigorous attempts by governments of various persuasions in PNG to curb that freedom. I will refer shortly to some of the more serious. Papua New Guinea has an international reputation for lawlessness and strife. The Times of London referred to Port Moresby as one of the most dangerous capitals on earth. But PNG could possibly teach the rest of the world a thing or two about preserving press

PACIFIC JOURNALISM REVIEW 5:1 199899 


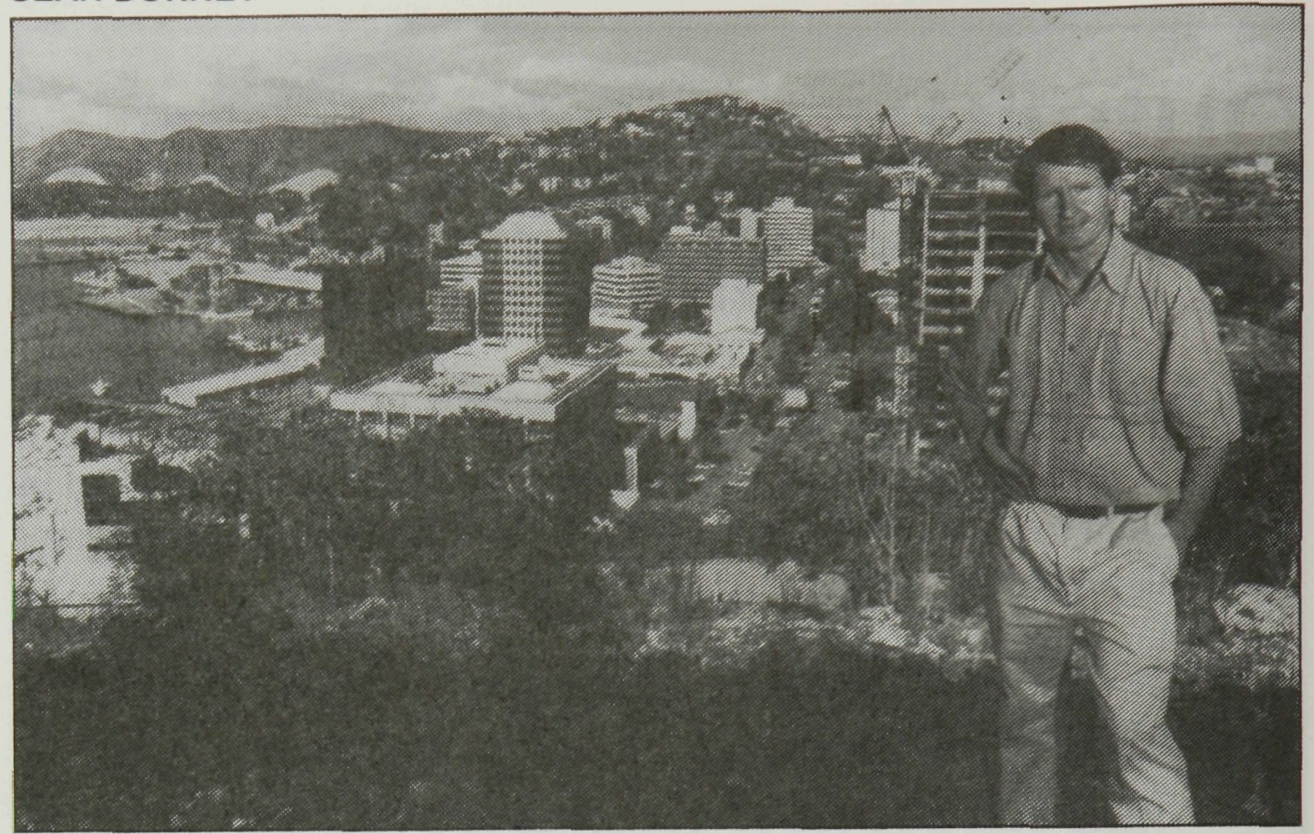

Sean Dorney in Port Moresby: Exposing the politicians.

freedom. What has worked in the media's favour in Papua New Guinea is the country's vibrant, you could say rampant, democracy. Papua New Guineans speak 876 languages and at least one person from each of these 876 societies believes he could or should be Prime Minister. There has never been a one-party government in PNG and, unless there is some radical change to the way the country operates, there will not be in the foreseeable future. At the 1997 national elections political parties did worse than ever. No fewer than 40 of the 109 members elected stood as Independents. Of the parties that did win seats, three have disappeared already and another two have split. Uneasy coalitions of convenience constrain any leader's dictatorial tendencies.

Freedom of expression is guaranteed by the PNG Constitution and any constitutional change to inhibit it requires a massive majority vote in the Parliament. That vote must be passed by that large majority twice at votes at least two months apart. No member of the Opposition in Papua New Guinea wants to surrender any of his or her current wide-open access to the media. And most members of Government know that the chances are that they won't be in power for long. The combination of five yearly national elections and regularly successful challenges on the floor of Parliament through votes of no confidence has meant that there has been a change of Prime Minister in PNG on average 100 PACIFIC JOURNALISM REVIEW 5:1 1999 


\section{PNG stories win six Walkleys}

THE MAINSTREAM Australian media has often ignored the Pacific Islands region. But in December 1998, when the Walkley Award winners were announced, no fewer than six categories were won by media people for work done in the region - most for items dealing with Papua New Guinea's tragic Aitape tsunami disaster in July.

Sean Dorney, the long time Australian Broadcasting Corporation correspondent in PNG, won the Radio News Reporting Walkley for his entries "PNG Tidal Wave 1-2-3-4"; Mark Davis and Peter McEvoy, who work for ABC TV's Four Corners, won two Walkleys - Best Current Affairs Feature and Best International report - for their documentary, "The Survivors' Story" dealing with how the Warapu people were readjusting to life; the Agence France-Presse duo, Sarah Stewart and Jack Taylor, won the Electronic Journalism Walkley for their coverage of the tsunami; and a photographer with The Australian; Patrick Hamilton, won the Best Feature Photograph Walkley for his shot of four children with amputated limbs playing in the rehabilitation ward at Wewak hospital.

The sixth 1998 Walkley awarded for a PNG story went to ABC TV News for "The Skate Tapes - showing secretly shot footage of PNG's Prime Minister, Bill Skate, allegedly authorising the payment of bribes and boasting of being the "Godfather" of Port Moresby's rascal gangs.

The previous year, 1997, The Australian's South Pacific correspondent, Mary-Louise O'Callaghan, won the Australian media industry's top journalism award, the Gold Walkley, for breaking the story of the Chan Government's hiring of the Sandline International mercenary group to try to crush the Bougainville rebels and reopen the Panguna copper mine.

every two-and-a-half years since 1980.

This does not mean that those in charge in PNG have not tried to introduce repressive media laws. In 1987, the Government, then led by Paias Wingti, wanted to set up a Media Tribunal with powers to license the media, the licences to be reviewed every 12 months. Wingti's Communications Minister, Gabriel Ramoi, hired an Australian lawyer, Stuart Littlemore, to draft the necessary legislation. But the proposals met considerable resistance. The Catholic Church threatened to mobilise its one million followers in opposition. Ramoi 


\section{SEAN DORNEY}

could never even get the numbers to introduce his Media Tribunal Bill to Parliament and he eventually abandoned the whole idea. He later went to jail when found guilty of misusing public money - a news item that, I might say, was well covered by the PNG press - but that is another story.

We had a similar surge of public support for the media's independence in 1996 when the Government led by Sir Julius Chan gave the Constitutional Review Commission the job of up with ways of making the media more "accountable". Again, the public was not convinced, apparently believing the media was far more accountable than the politicians! Chan's constitutional reference required the Commission which was headed by a politician from Sir Julius's own party, Ben Micah, to determine whether changes were needed "to ensure" that "owner, editors and journalists of all elements of the media" were accountable and that "persons aggrieved by media abuses" had "accessible redress". The use of this word "persons" intrigued me. I went on a search through my rather extensive news files at the ABC bureau to try to establish who all these poor, victimised "persons" might have been. Surely, I figured, they would be the ones complaining loudest.

Well, wonder of wonders, Ben Micah, the chairman of the Constitutional Commission, was one. In a report I had done for the ABC in August 1995, I quoted from a "blast" Micah had given The Independent newspaper for a front page story saying two sacked ministers had asked the Ombudsman Commission to investigate Micah for alleged irregularities and abuse of privileges. He attacked the newspaper, accusing it of biased, shallow and anti-government reporting and said he would support moves to make the media more accountable. I also pulled out a media statement from the Office of the Prime Minister dated November 1995, in which Sir Julius Chan himself was quoted as "lashing out" against what he described as "unwarranted and insensitive attempts by the mass media to discredit leaders in Papua New Guinea".

Delving further into the file, I found another "person" angry with the media for the alleged wrong it had done him. This time it was the Media Minister in 1990, Brown Sinamoi, complaining that newspapers "only know how to expose leaders". He called on his fellow parliamentarians not to let the press "dictate to us ... Instead, we should tell them what they should report and what they should not". Another politician, the late Galen Lang, was there in the file too, venting his anger at journalists in 1991 attacking them for being, in his words, the "root cause" of PNG's law and order problems. "We have become the victims of these money making idiots," he said. "I wish criminals would bash up journalists." 102 PACIFIC JOURNALISM REVIEW 5:1 1999 
Hard as I looked, though, I could not find anybody in the file attacking journalists who was not from this single profession - they were all politicians.

Although Members of Parliament in PNG have failed in their various attempts to muzzle the media, this lack of political potency unfortunately carries over into their rather lax control, when in power, over the various agencies of government which are only too happy to impose unlawful and unconstitutional curbs on journalists trying to do their job. I have run into numerous, often quite low rung, officials in quite a number of locations around PNG who have scant regard for the law or the constitution. The further from the seat of power, the capital, Port Moresby, the more autocratic and obstructive these officials appear to be.

In March 1993, I was in Wabag, the capital of Papua New Guinea's last declared province, Enga - right up the far end of the Highlands Highway trying to film the wreckage that arsonists had made of the Enga Provincial Government headquarters. The Provincial Government had been suspended for gross financial mismanagement. All the records went up in flames. I went to interview the newly appointed Administrator. He was not there and when the man third in charge eventually did allow me into his temporary office, he forbade me from shooting the damage on video or doing a story.

"Under what law?" I asked him. He said he was in charge and he was stopping me because it would be bad for foreign investment. I suggested he should talk to the arsonists not me if he was worried about the confidence foreign investors might have in Enga but he said he would order the police to arrest me if I did not leave town. We did the story without him.

Without doubt, though, the most difficult and perhaps most dangerous story to cover in Papua New Guinea in the last decade has been the secessionist war on Bougainville. I have been there more than any other non-PNG journalist but that is something of an idle boast because I' $m$ based in PNG and the only other Australian media organisation with a bureau there, Australian Associated Press, has had five correspondents over the same period. But it has given me a rich source of anecdotes about run-ins with the PNG military.

In late 1992, I won permission from the head of the PNG Prime Minister's Department, who is also the chairman of PNG's National Security Advisory Council, to spend a week in Bougainville doing a comprehensive story on Resistance Groups - the local militia that had been set up in many villagers in the north of Bougainville who were taking the war to the Bougainville Revolu- 


\section{SEAN DORNEY}

tionary Army because they were fed up with the conflict and wanted life to return to normal. The whole Bougainville issue is far too complex to go into here but I'll just describe how little regard the military at Wakunai had for any clearance I had obtained from the national government. My camera team and I were rounded up shortly after dawn after our first night on the Bougainville mainland. Our cameraman was heading for a latrine with a roll of toilet paper in hand when the soldiers drove up. They were heavily armed and Wayne Harley nervously joked with them saying, "I hope you haven't come to shoot us." Never was a toilet roll more handily placed when one of the soldiers replied, "Yes, we have!" We were not shot but arrested at gunpoint, had our tapes confiscated, were taken to an airstrip and ordered to leave on a chartered plane they arranged.

On another occasion, a corporal overruled the authority I had received from the civilian government to travel into Bougainville with the Red Cross. And once, up near the Papua New Guinea/Indonesian border, I had permission from the then Prime Minister, Sir Rabbie Namaliu, to travel into the bush where a band of Free West Papua, OPM, rebels were holding a number of missionaries hostage. They had captured them at the border station at Amanab and one of their demands was to be allowed to speak to me so I could report their demands over Radio Australia. Sir Rabbie thought it might be a way to establish some contact with the group. But the military intelligence sergeant at Amanab placed me under house arrest saying bluntly that in Amanab, the PNG Prime Minister had no clout. "This is my turf," was this sergeant's bombastic and arrogant boast and he waved his loaded automatic weapon at me, his face twitching. I could go on and on about how the military in PNG - at least up until the Sandline mercenaries fiasco of March 1997 - have taken no notice of civilian authority or direction when it comes to dealing with the media.

I was once placed under house arrest in another Melanesian country too. In the South Pacific there can be a fine line between attempts at repression and farce. I was trying to cover the Solomon Islands elections and, for some inexplicable reason, the then Solomon Islands Prime Minister, Solomon Mamaloni, didn't seem to want his people's demonstration of active democracy to be told or broadcast to the rest of the world. He issued instructions that no foreign media personnel were to be allowed into the country to cover the elections. However, Chris Pash, the Australian Associated Press Correspondent then based in Port Moresby, slipped into the Solomon Islands from PNG while I arrived at midnight from Brisbane. At that late hour the Migration and Customs officials at Honiara's Henderson airfield did not quite know what to do with me. 104 PACIFIC JOURNALISM REVIEW 5:1 1999 
After I surrendered them my passport, they let me in.

The next day both Chris and I were summoned to the Solomon Islands Foreign Affairs Department and told that as journalists we had no government clearance to be in Solomon Islands and that we were being placed under house arrest at the Mendana Hotel until the next flights back to Papua New Guinea and Australia. Ironically there was no attempt made to limit our ability to make telephone calls. So from the comfort of the Mendana's open-air bar we covered the count and reported the election result. Prime Minister Mamaloni was returned and my house arrest came to an abrupt end on the Sunday morning. I received a phone call from Ashley Wickham, then head of the Solomon Islands Broadcasting Corporation, asking me how good a cricketer I was. "I can bowl a bit but I'm not much of a batsman," I replied. "That's fine," he replied. "The Prime Minister's cricket team is one man short! There'll be a car to pick you up in half an hour."

Writing a few years ago about the Eurocentric media fascination with allegedly lost tribes in Papua New Guinea, Rowan Callick, one of the better journalists to cover the Pacific and Asia for the Australian media, told a story of how, when he was group manager with The Times of PNG, the London Daily Mail ran a breathless report about how an intrepid group of British students travelling the world led by the magnificently named Colonel Blashford-Snell had "discovered" a lost tribe in PNG's Eastern Highlands. This tribe allegedly had had no knowledge or contact with white men before. Rowan said that when this report landed on his desk in Port Moresby, William Williando, one of PNG's best news photographers looked over his shoulder and said in some disbelief, "That's my tribe! Rowan, that's my tribe they've named."

But I would argue that the Commonwealth Press Union is not here to try to defend that sort of ignorant mis-reporting by the foreign media. Rather, it is the local media in the various countries of the Commonwealth that the CPU is trying to support and strengthen. In Papua New Guinea, the country I can speak a little about, it is the local media that is exposing what is wrong and that is keeping the public properly informed. I am pleased to say that among the papers doing that is The National, majority owned by Malaysian interests, whose editor, Frank Kolma, deserves to have his fearlessness in exposing inconsistencies in policy and corruption in public life in PNG greatly commended. To my mind, in Papua New Guinea it is the local media that deserves the praise for fighting to preserve media freedom. 


\section{SEAN DORNEY}

A little earlier I spoke of not being able to find in my files anybody except PNG politicians who had expressed a public grievance against the media. I found plenty of others, though, defending the press and the right to publish in the public interest. One of the most eloquent defences came from the former Anglican Bishop of Port Moresby, Sir David Hand. I reread a copy of the speech he made when PNG's quality weekly, The Independent, was launched. Word Publishing, which brings out The Independent, is owned by the major Christian churches in PNG and Bishop Hand spelt out the ambitions of that company ambitions that I believe almost all sections of the media in Papua New Guinea could be said to aspire to uphold. They might hold true in other developing countries just as well. Bishop Hand said these ambitions were that:

One, truth may be spoken and served, without fear or favour; and Two, that the political and economic life as well as the spiritual and, social life of our nation may be purged of so much that corrupts it and [purged] of the ignorances which inoculate simple unlettered people - rural and urban - against their own ability to make informed and objective judgements, and to act upon them.

That, to me, beautifully sums up the argument against the proposition that governments have a duty to regulate the media and that the media itself has invented the "need to know".

$\square$ Sean Dorney is currently Brisbane-based South Pacific Correspondent of the Australian Broadcasting Corporation. He was formerly the ABC's bureau chief in Papua New Guinea. He presented this paper at a session on "Reporting under repressive regimes" at the Commonwealth Press Union Biennial Conference at Kuala Lumpur, 26-29 October 1998, under the original title, "Outmanoeuvring media repression in Melanesia". Dorney is also author of The Sandline Affair; Politics, Mercenaries and the Bougainville Crisis.

Email: dorney.sean@a2.abc.net.au 